\title{
The Biosynthesis of Transfer Ribonucleic Acid in the Developing Rat Brain and in Cultured Glial Cells
}

\author{
O. Z. Sellinger and O. Der \\ Laboratory of Neurochemistry, Mental Health Research Institute, University of Michigan Medical Center, \\ Ann Arbor, Michigan 48109, U.S.A.
}

\begin{abstract}
The biosynthesis of tRNA was investigated in cultured astroglial cells and the 3-day-old rat brain in vivo. In the culture system astrocytes were grown for 19 days and were then exposed to $\left[{ }^{3} \mathrm{H}\right]$ guanosine for $1.5-7.5 \mathrm{~h}$; 3-day-old rats were injected with $\left[{ }^{3} \mathrm{H}\right]$ guanosine and were killed 5-45 min later. $\left[{ }^{3} \mathrm{H}\right]$ tRNA was extracted, partially purified, and hydrolyzed to yield $\left[{ }^{3} \mathrm{H}\right]$ guanine and $\left[{ }^{3} \mathrm{H}\right]$ methyl guanines. The latter were separated from the former by high performance liquid chromatography and their radioactivity determined as a function of the time of exposure to $\left[{ }^{3} \mathrm{H}\right]$ guanosine. The findings indicate that labeling of astrocyte tRNA continued for $7.5 \mathrm{~h}$ and was maximal, relative to total RNA labeling, at $3 \mathrm{~h}$, while in the immature brain tRNAs were maximally labeled at $20 \mathrm{~min}$ after $\left[{ }^{3} \mathrm{H}\right]$ guanosine administration. The labeling pattern of the individual methyl guanines differed considerably between astrocyte and brain tRNAs. Thus, $\left[{ }^{3} \mathrm{H}\right] 1$-methylguanine represented up to $35 \%$ of the total $\left[{ }^{3} \mathrm{H}\right]$ methyl guanine radioactivity in astrocyte $\left[{ }^{3} \mathrm{H}\right] \mathrm{tRNA}$, while it became only negligibly labeled in brain $\left[{ }^{3} \mathrm{H}\right] \mathrm{tRNA}$. Conversely, brain $\left[{ }^{3} \mathrm{H}\right] \mathrm{tRNA}$ contained more $\left[{ }^{3} \mathrm{H}\right] \mathrm{N}^{2}$-methylguanine than did astrocyte $\left[{ }^{3} \mathrm{H}\right] \mathrm{tRNA}$. Approximately equal proportions of $\left[{ }^{3} \mathrm{H}\right] 7$-methylguanine were found in the $\left[{ }^{3} \mathrm{H}\right] \mathrm{tRNAs}$ of both neural systems. The $\left[{ }^{3} \mathrm{H}\right]$ methylguanine composition of brain $\left[{ }^{3} \mathrm{H}\right] \mathrm{tRNA}$ was followed through several stages of tRNA purification, including benzoylated DEAE-cellulose and reverse phase chromatography (RPC-5), and differences were found between the $\left[{ }^{3} \mathrm{H}\right]$ methylguanine composition of $\mathrm{RPC}-5$ fractions containing, respectively, tRNA ${ }^{\text {lys }}$ and $t R N A^{\text {phe }}$. The overall results of this study suggest that developing brain cells biosynthesize their particular complement of tRNAs actively and in a cell-specific manner, as attested by the significant differences in the labeling rates of their methylated guanines. The notion is advanced that cell-specific tRNA modifications may be a prerequisite for the successful synthesis of cell-specific neural proteins. Key words: Transfer ribonucleic acids-Biosynthesis-Brain development-AstrocytesMethyl guanines. Sellinger $O$. Z. and Der $O$. The biosynthesis of transfer ribonucleic acid in the developing rat brain and in cultured glial cells. $J$. Neurochem. 35, 1436-1445 (1980).
\end{abstract}

The extranuclear portion of the biosynthetic process leading to cerebral nucleic acids and, in particular, to transfer ribonucleic acids (tRNAs) and their isoacceptors, comprises the subprocesses of: (a) polynucleotide assembly, (b) precursor tRNA trimming, and (c) specific structural modification(s) of the precursor and/or the mature tRNA species. Very little is known about any of these phenomena and of the mechanisms governing them (see review by Sellinger and Salas, 1980). Volpe and Giuditta (1967) noted a lower incorporation of $\left[{ }^{14} \mathrm{C}\right]$ orotic acid into glial than into neuronal total RNA in the adult rabbit, while Flangas and Bowman (1970) reported a lower incorporation of $\left[{ }^{3} \mathrm{H}\right]$ orotic acid and of $\left[{ }^{3} \mathrm{H}\right]$ cytidine into the RNA of glial-relative to neuronal-enriched rat brain fractions. Jarlstedt and
Received March 24, 1980; accepted May 19, 1980.

Abbreviations used: BDC, Benzoylated-DEAE cellulose;
DEPC, Diethylpyrocarbonate; RPC, Reversed phase chromatography; TNE, $0.01 \mathrm{M}$-Tris $+0.1 \mathrm{M}-\mathrm{NaCl}+0.01 \mathrm{M}$-EDTA. 
Hamberger (1971) incubated adult rabbit brain cortex slices in the presence of $\left[{ }^{3} \mathrm{H}\right]$ uridine and found the labeling of the glial RNA to be more pronounced than that of neuronal RNA. More recently, Kubat et al. (1978) examined the in vitro incorporation of $\left[{ }^{3} \mathrm{H}\right]$ uridine into RNA of rat brain glial-enriched fractions and discovered that a 6-day dietary restriction in protein intake specifically suppressed RNA labeling in the young animals used in the study. Yanagihara (1979) observed markedly higher rates of RNA formation in "intact" glial cells than in neuronal perikarya, a finding attributed to the preferentially reduced uptake by the perikarya of the RNA precursors, $\left[{ }^{3} \mathrm{H}\right]$ uridine and $\left[{ }^{3} \mathrm{H}\right]$ guanosine.

The specific biosynthesis of tRNA has also been studied in vivo, yet mostly as part of isotope incorporation studies involving other brain RNA species. However, Saborio and Aleman (1970) noted the exclusive labeling of tRNA for about $\mathbf{4 0}$ min following the intracerebral administration of $\left[{ }^{14} \mathrm{C}\right]$ uridine and $\mathrm{L}-\left[\mathrm{Me}-{ }^{3} \mathrm{H}\right]$ methionine to 18 -day-old rats, while Judes and Jacob (1973) described the dynamics of $\left[{ }^{3} \mathrm{H}\right]$ uridine incorporation into, inter alia, the tRNA of chick embryo brain extracts. More recently, Azcurra et al. (1975) demonstrated a rapid incorporation of $\left[{ }^{3} \mathrm{H}\right.$ ] uridine into the tRNA of 8-day-old rat brain neuronal perikarya, while Tewari et al. (1975) examined the effects of ethanol in vivo on the incorporation of $\left[{ }^{3} \mathrm{H}\right]$ orotic acid into mouse brain tRNA. Evidence from our laboratory has demonstrated the existence and the time course of formation of precursor tRNA molecules in the 3-day-old rat brain (Elahi and Sellinger, 1979). We have also shown that homologous methylation of brain tRNA (Cummins et al., 1975) persists for up to 1 month after birth (Salas et al., 1976) and that many of the cerebral tRNA methyltransferases continue to alter their substrate recognition characteristics and hence their specificity for as long as $\mathbf{4 0}$ days postnatally (Sellinger et al., 1977; Dainat et al., 1978; Dainat and Sellinger, 1980).

In the present study we examine the biosynthesis of tRNA in two distinct neural systems, namely, cultured glial cells (astrocytes) and the 3-day-old rat brain in vivo.

\section{EXPERIMENTAL PROCEDURES}

\section{Chemicals}

DEAE-cellulose (DE23, Whatman) was from ReeveAngel, Clifton, New Jersey. For BDC-chromatography, Cellex-BD (100-200 mesh) was obtained from Bio-Rad, Richmond, California. For reverse-phase chromatography, the solid support material, RPC-5, was a generous gift of Dr. G. D. Novelli, Oak Ridge, Tennessee. Diethyl pyrocarbonate (DEPC) was from Accurate Chemical and Scientific Co., Hicksville, New York, $\left[8{ }^{3} \mathrm{H}\right]$ guanosine (15 $\mathrm{Ci} / \mathrm{mmol}$ ) was from New England Nuclear, Boston, Mas- sachusetts; L- $\left[\mathrm{U}-{ }^{14} \mathrm{C}\right]$ lysine $(270-345 \mathrm{mCi} / \mathrm{mmol})$ from ICN, Irvine, California, Amersham Corp., Arlington Heights, Illinois, or NEN, Boston, Massachusetts; L$\left[4,5-{ }^{3} \mathrm{H}\right]$ lysine $(75-78 \mathrm{Ci} / \mathrm{mmol})$ from Amersham Corp or from NEN; L-[U- $\left.{ }^{14} \mathrm{C}\right]$ phenylalanine $(450-536 \mathrm{mCi} / \mathrm{mmol})$ from NEN or Research Products International, Elk Grove, Illinois; and $\mathrm{L}-\left[2,4,6-{ }^{3} \mathrm{H}\right]$ phenylalanine $(71 \mathrm{Ci} /$ mmol) from Amersham Corp.

\section{Animals}

The 3- and 18-day-old rats were of the Sprague-Dawley strain. The 3-day-old animals were used at the earliest 24 $\mathrm{h}$ after arrival from the shippers (Spartan Farms, Haslett, Michigan). They were housed in cages containing one family/cage.

\section{Tissue Culture}

All materials used were as previously described (Cummins and Glover, 1978; Cummins et al., 1979). The cell culture procedure used in this study was also as previously described (Cummins and Glover, 1978). However, the size of the culture dishes and hence of the surface area available for cell growth was varied to obtain the best conditions for maximum yields of $A_{260}$ (absorbance units) and therefore of RNA. For RNA extraction, the cultures were handled as follows. The growth medium was decanted and the cells rinsed twice with phosphate-buffered saline containing (in g/liter): $\mathrm{CaCl}_{2}$ and $\mathrm{MgCl}_{2}, 0.1 ; \mathrm{KCl}$ and $\mathrm{KH}_{2} \mathrm{PO}_{4}, 0.2 ; \mathrm{NaCl}, 8$; and $\mathrm{Na}_{2} \mathrm{HPO}_{4}, 2.15$. Equal volumes of TNE buffer $(0.01 \mathrm{M}$-Tris- $\mathrm{HCl}, \mathrm{pH} 7.8,0.1$ $\mathrm{M}-\mathrm{NaCl}, 0.01 \mathrm{M}-\mathrm{NaEDT} A)$ in DEPC-treated distilled water $(0.5 \mathrm{ml} \mathrm{DEPC/liter} \mathrm{of} \mathrm{water} \mathrm{was} \mathrm{boiled} \mathrm{for} 15 \mathrm{~min}$ and cooled), containing also $10 \mathrm{~mm}-\mathrm{MgCl}_{2}$ and $\beta$ mercaptoethanol, $\mathrm{pH} 8.2$, were mixed with TNEsaturated phenol. Ten milliliters of this mixture were used for transfer of the cells into a test tube which was agitated for $5 \mathrm{~min}$ on a Vortex Junior mixer, following the addition of $5 \mathrm{ml} \mathrm{CHCl}$. The extraction was continued in a shaking water bath, set to $60^{\circ} \mathrm{C}$, for an additional $40 \mathrm{~min}$. After centrifugation $(9000 \times \mathrm{g}, 15 \mathrm{~min}), 3$ vols. of $95 \%(\mathrm{v} / \mathrm{v})$ EtOH were added to the separated aqueous layer and the RNA was allowed to precipitate overnight at $-20^{\circ} \mathrm{C}$. In the labeling experiments each $5 \mathrm{ml}$ of growth medium also contained $62.5 \mu \mathrm{Ci}$ of $\left[{ }^{3} \mathrm{H}\right]$ guanosine. The 19-day-old cells were grown in $75-\mathrm{cm}^{2}$ dishes and their RNA was extracted at intervals, as specified in the text.

\section{In Vivo Labeling and Extraction of Brain tRNA}

In these experiments, $4 \mu \mathrm{Ci}$ of $\left[{ }^{3} \mathrm{H}\right]$ guanosine/g of body weight was injected intracranially and the brains were removed for RNA extraction 5-45 min thereafter. The cerebral cortices were homogenized in $0.25 \mathrm{M}$-sucrose containing $35 \mathrm{~mm}$-Tris- $\mathrm{HCl}, \mathrm{pH} 7.4,25 \mathrm{~mm}-\mathrm{KCl}$ and - $\mathrm{MgCl}_{2}, 1 \mathrm{~mm}$-sodium EDTA, $10 \mathrm{~mm}-\beta$-mercaptoethanol and $0.05 \%$ DEPC. The homogenate was centrifuged for 20 min at $30,000 \times g$; the low-molecular-weight RNA was extracted from the resulting supernatant by the procedure of Ortwerth and Der (1974). 


\section{Purification, Hydrolysis, and Compositional Analysis of $t R N A$}

Following extraction the RNA was precipitated with ethanol and, as above for astrocyte RNA, it was stored overnight at $-20^{\circ} \mathrm{C}$. Following centrifugation, it was redissolved in $10 \mathrm{~mm}$-Tris- $\mathrm{HCl}$, containing $10 \mathrm{mM}-\mathrm{MgCl}_{2}, 1$ mM-EDT A, and $50 \mathrm{~mm}-\mathrm{NaCl}, \mathrm{pH} 7.5$ (buffer $\mathrm{A}$ ), and the sample was loaded on a column of DEAE-cellulose previously equilibrated with buffer $A$. Elution with buffer $A$ was continued until the $A_{260}$ reading fell below 0.05 . Next, the column was rinsed with buffer $A$ containing $0.3 \mathrm{M}$ $\mathrm{NaCl}$ until an $\mathrm{A}_{260}$ reading of 0.05 was reached. Finally, the tRNA-containing fraction was eluted with buffer $A$ containing $0.7 \mathrm{M}-\mathrm{NaCl}$. The tubes exhibiting $\mathrm{A}_{260} / \mathrm{A}_{280} \mathrm{val}-$ ues in excess of 1.5 were pooled and dialyzed to remove $\mathrm{NaCl}$. Following lyophilization, the tRNA was hydrolyzed in trifluoracetic acid (Klagsbrun, 1972) and the $\left[{ }^{3} \mathrm{H}\right]$ guanine and $\left[{ }^{3} \mathrm{H}\right]$ methyl guanines were separated by HPLC according to Salas and Sellinger (1977). To achieve the separation of guanine from 1-methylguanine and of the latter base from the remaining $\left[{ }^{3} \mathrm{H}\right]$ methylguanines, $50 \mathrm{mM}$-ammonium phosphate $+1 \mathrm{M}-\mathrm{NH}_{4} \mathrm{Cl}$ in $10 \%(\mathrm{v} / \mathrm{v})$ methanol was used as the single eluting buffer. The hydrolysis and HPLC separation of guanine from its methylated derivatives remained unchanged for tRNA preparations of higher purity (see text for details) than the material exiting from DEAE-cellulose.

\section{Benzoylated-DEAE-Cellulose Chromatography}

Chromatography on benzoylated DEAE-cellulose (BDC) was performed for further purification of tRNA and for the isolation of tRNA ${ }^{\text {phe }}$ and tRNA ${ }^{\text {lys }}$. Cellex-BD was washed and the column $(1 \times 20 \mathrm{~cm})$ was packed and prepared for use according to Roy et al. (1971). The equilibrating buffer was $50 \mathrm{~mm}$-sodium acetate, $\mathrm{pH} 5.0$, containing $10 \mathrm{~mm}-\mathrm{MgCl}_{2}$ and $0.3 \mathrm{M}-\mathrm{NaCl}$. tRNA (up to $200 \mathrm{~A}_{260}$ units), dissolved in the equilibrating buffer, was loaded and the elution was carried out with $120 \mathrm{ml}$ of a $0.5-1.0 \mathrm{M}-\mathrm{NaCl}$ gradient in the above buffer, followed by $120 \mathrm{ml}$ of a $0-30 \%(\mathrm{v} / \mathrm{v})$ ethanol gradient containing 1 $\mathrm{M}-\mathrm{NaCl}$ in buffer. The flow rate was adjusted to $2 \mathrm{ml} / \mathrm{min}$ and $5-\mathrm{ml}$ fractions were collected. All solutions used in BDC chromatographic work also contained $0.04 \%$ sodium azide. Aliquots $(0.1 \mathrm{ml})$ of each effluent fraction were mixed with scintillant and their radioactivity was determined. Up to $0.5 \mathrm{ml}$ was taken for the aminoacylation assay (see below).

\section{RPC-5 Chromatography}

The procedure described by Kelmers and Heatherly (1971) was adapted to a $0.9 \times 50 \mathrm{~cm}$ column which was operated at approx. $250 \mathrm{psi}$. Elution was carried out using $200 \mathrm{ml}$ of a gradient of $0.5-1.0 \mathrm{M}-\mathrm{NaCl}$ prepared in 10 mM-sodium acetate, $10 \mathrm{~mm}-\mathrm{MgCl}_{2}, 1 \mathrm{~mm}$-EDTA, and 30 mM- $\beta$-mercaptoethanol, $\mathrm{pH} 4.5$.

\section{Preparation of Aminoacyl-tRNA Synthetases}

Livers or brains (approx. $10 \mathrm{~g}$ ) of adult rats were homogenized in 2 volumes of buffer containing $0.25 \mathrm{M}$ - sucrose, $50 \mathrm{~mm}-\mathrm{KCl}, 10 \mathrm{~mm}-\mathrm{Tris}-\mathrm{HCl}, \mathrm{pH} 7.5,10 \mathrm{~mm}$ $\mathrm{MgCl}_{2}, 0.01 \mathrm{~mm}-\beta$-mercaptoethanol, and $10 \%(\mathrm{v} / \mathrm{v})$ glycerol. The homogenate was centrifuged as above for tRNA extraction and the supernatant was recentrifuged for $75 \mathrm{~min}$ at $160,000 \times g$. The resulting supernatant $(10-30 \mathrm{ml})$ was passed through a column of Sephadex G-75 $(2.5 \times 75 \mathrm{~cm})$ previously equilibrated with Tris $-\mathrm{HCl}$ (50 $\mathrm{mm}, \mathrm{pH} 7.5$ ), containing $10 \mathrm{mM}-\mathrm{KCl},-\mathrm{MgCl}_{2}$, and $-\beta$-mercaptoethanol and $10 \%$ glycerol. Elution was at 1 $\mathrm{ml} / 3 \mathrm{~min}$ and fractions of $3.5 \mathrm{ml}$ were collected. Fractions $23-25$ were stored at $-20^{\circ} \mathrm{C}$ following addition of glycerol to $50 \%(\mathrm{v} / \mathrm{v})$.

\section{tRNA Aminoacylation}

\section{After chromatography on BDC or \\ RPC-5 (post-charging)}

tRNA was aminoacylated in a reaction volume of $1 \mathrm{ml}$ containing in order of addition: $1 \mu \mathrm{Ci}$ of ${ }^{14} \mathrm{C}$ or ${ }^{3} \mathrm{H}$ amino

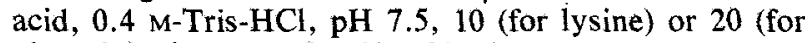
phenylalanine) $\mathrm{mM}^{-} \mathrm{MgCl}_{2}, 20$ (for lysine) or 50 (for phenylalanine) $\mathrm{mM}-\mathrm{KCl}, 1$ (for lysine) or 4 (for phenylalanine) $\mathrm{mm}-\mathrm{ATP}, 0.6 \mathrm{~mm}-\mathrm{CTP}, 2 \mathrm{~mm}-\beta-$ mercaptoethanol, $0.1-0.5 \mathrm{~A}_{260}$ units of tRNA and approx. $1 \mathrm{mg}$ of hepatic or cerebral aminoacyl-tRNA synthetase protein. Following incubation for $10 \mathrm{~min}$, at $37^{\circ} \mathrm{C}$ and with gentle shaking, the reaction was stopped by placing the tubes on ice, adding $5 \mathrm{ml}$ of ice-cold $10 \%$ trichloroacetic acid and collecting the radioactive aminoacyl-tRNA on Whatman GF/A filters, which were processed for counting according to Yang and Novelli (1971).

\section{Before chromatography on BDC or RPC-5 (pre-charging)}

This was carried out on amounts of tRNA in excess of 1 $\mathrm{A}_{260}$ unit in a final volume of $1 \mathrm{ml}$, containing $1-5 \mu \mathrm{Ci}$ of amino acid, $0.2 \mathrm{M}$-Tris- $\mathrm{HCl}, \mathrm{pH} 7.5,10 \mathrm{~mm}-\mathrm{MgCl}_{2}, 20$ $\mathrm{mm}-\mathrm{KCl}, 1 \mathrm{~mm}-\mathrm{ATP}, 3 \mathrm{~mm}-\mathrm{CTP}, 8 \mathrm{~mm}-\beta$-mercaptoethanol, and $10-15 \mathrm{mg}$ of hepatic aminoacyl-tRNA synthetase protein. The tRNA was not deacylated before use because it was of primary interest to determine the acceptance capacity of the available, "native," uncharged tRNA species.

\section{Protein Determination}

The procedure of Lowry et al. (1951) was used with crystalline bovine serum albumin as standard.

\section{RESULTS \\ Optimization of Growth Conditions for Maximal RNA Yields}

The examination of the effect of the surface area of the culture dish and of time of culture on the yield of extractable $A_{260}$ units/20 dishes resulted in maximal yields after 19 days in $75-\mathrm{cm}^{2}$ dishes. Cultures so grown were exposed to $\left[{ }^{3} \mathrm{H}\right]$ guanosine (see Methods) for $0.5-7.5 \mathrm{~h}$ and, at intervals, total RNA was extracted and its radioactivity determined. Figure 1, A indicates that the labeling of the RNA 

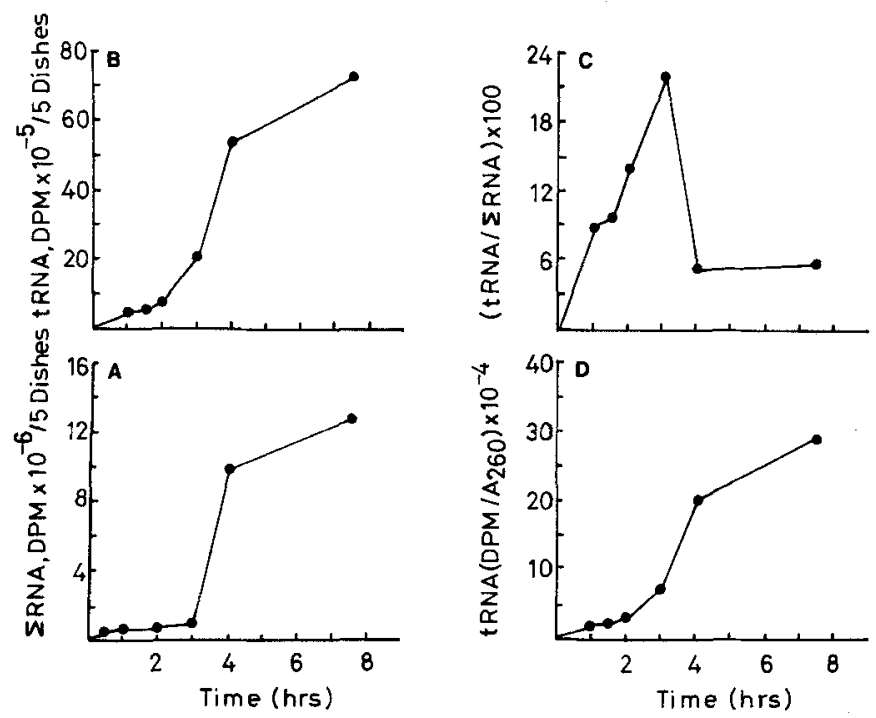

FIG. 1. Time course of $\left[{ }^{3} \mathrm{H}\right]$ guanosine incorporation into astroglial RNA. (A) Radioactivity of total RNA as a function of culture time; (B) radioactivity in tRNA, as a function of culture time. A and $B$ refer to d.p.m. recovered in total RNA and tRNA, extracted from five $75-\mathrm{cm}^{2}$ culture dishes and purified through the DEAE-cellulose step (see Methods). (C) Percent labeling of tRNA relative to total RNA, as a function of culture time; (D) the specific radioactivity of tRNA as a function of culture time. There were 3.4, 2.8, $3.2,3.2,2.6$, and 5.3 tRNA $A_{260}$ units at $1,1.5,2,3,4$, and $7.5 \mathrm{~h}$, respectively.

lagged at first and then increased to near-maximal levels between the 3rd and 4th h. Figure 1, B indicates a more gradual labeling pattern for tRNA. As shown by Fig. 1, C, the percentage of labeled tRNA relative to the total RNA peaked at $3 \mathrm{~h}$. The specific radioactivity of astrocyte tRNA (Fig. 1, D) appeared to increase in parallel with the increase in its labeling.

\section{Aminoacylation of Brain and Astrocyte tRNA}

To assess the functional capacity of tRNA with respect to lysine and phenylalanine, preparations of astroglial and cerebral tRNA were charged with $\left[{ }^{14} \mathrm{C}\right]$ phenylalanine and $\left[{ }^{14} \mathrm{C}\right] \mathrm{ly}$ sine in assays employing both hepatic and cerebral aminoacyl tRNA-synthetase preparations. Table 1 indicates maximum charging under the heterologous condition, i.e., when liver enzyme catalyzed the aminoacylation of brain tRNA. Minimal charging values were obtained under conditions approximating homology, i.e., when brain enzyme catalyzed the aminoacylation of the presumably cell-specific glial tRNA. It is of interest to note that the aminoacylation of phenylalanine was uniformly inferior to that of lysine, particularly when astrocyte tRNA was the substrate. Closer inspection of the values in Table 1 further reveals that, whereas astrocyte tRNA was between 20- and 30-fold less efficient than brain tRNA in phenylalanine acceptance (compare 4.34 and 0.21 and 1.78 and 0.064 pmol), lysine acceptance by astrocyte tRNA was only three- to fivefold lower than by brain tRNA.

\section{Incorporation of $\left[{ }^{3} \mathrm{H}\right] \mathrm{Guanosine}$ into Astrocyte tRNA}

Astrocyte tPNA labeled for $1-3,4$, and $7.5 \mathrm{~h}$ was hydrolyzed to its ${ }^{3} \mathrm{H}$ bases, which were separated by HPLC and assayed for radioactivity. Figure 2 shows the radioactivity profile of a typical separation after $7.5 \mathrm{~h}$ of exposure of the astrocytes to $\left[{ }^{3} \mathrm{H}\right]$ guanosine. Table 2 lists: (a) the distribution of ${ }^{3} \mathrm{H}$ between guanine and the four principal $\left[{ }^{3} \mathrm{H}\right]-$ methyl guanines (1-, 7-, $\mathrm{N}^{2}$-methyl, and $\mathrm{N}_{2}^{2}-$ dimethyl guanine) as a function of time in culture (columns 1 and 2); (b) the distribution of ${ }^{3} \mathrm{H}$ among the four methylated guanines (columns 3-6); and (c) the percent of radioactivity in the four methylated guanines, after normalizing the sum of their radioactivity to $100 \%$ (values in parentheses). It may be seen that the labeling of guanine and of the methyl guanines remained sustained throughout the

TABLE 1. Amino acid acceptance of glial and brain $t R N A$

\begin{tabular}{lccccc}
\hline & \multicolumn{2}{c}{ Astrocyte tRNA } & & \multicolumn{2}{c}{ Brain tRNA } \\
\cline { 2 - 3 } \cline { 5 - 6 }$\left[{ }^{14}\right.$ C]Amino acid & Liver $^{a}$ & Brain $^{a}$ & & Liver $^{a}$ & Brain $^{a}$ \\
\hline Phenylalanine & 0.21 & 0.064 & & 4.34 & 1.78 \\
Lysine & 12.9 & 8.4 & & 77.9 & 22.4 \\
\hline
\end{tabular}

The incubations were for $10 \mathrm{~min}$. The $t R N A$ was tested after purification through DEAE-cellulose (see Methods) of material extracted from 19day-old astrocyte cultures and 3-day-old rat brain. For other details, see Methods. The values are expressed as picomoles per $A_{260}$ unit per milligram of synthetase protein

a Source of aminoacyl tRNA-synthetase. 


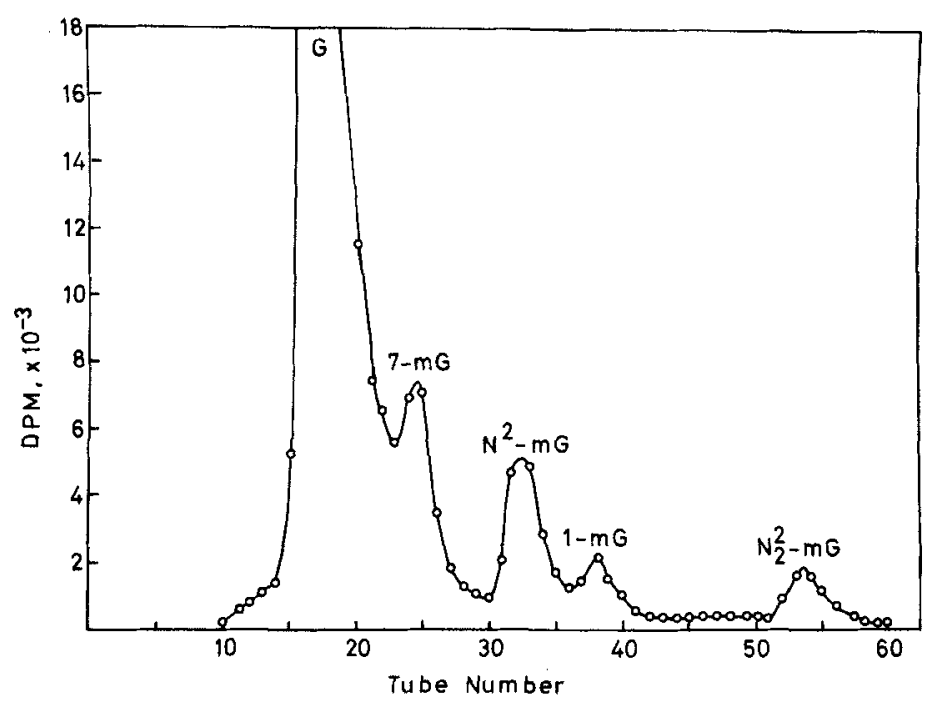

FIG. 2. Separation by HPLC of tRNA $\left[{ }^{3} \mathrm{H}\right]$ guanine from tRNA $\left[{ }^{3} \mathrm{H}\right]$ methyl guanines. $\left[{ }^{3} \mathrm{H}\right]$ tRNA was extracted from astroglial cells cultured for 19 days in $2075-\mathrm{cm}^{2}$ culture dishes and was purified by passage through DEAE-cellulose (see Methods). An aliquot containing approx. 700,000 d.p.m. was hydrolyzed in trifluoroacetic acid and the resulting $\left[{ }^{3} \mathrm{H}\right]$ bases were separated by $\mathrm{HPLC}$, as described in Methods. The $\left[{ }^{3} \mathrm{H}\right]$ guanine peak accounted for $90.9 \%$ of the total $\left[{ }^{3} \mathrm{H}\right]$ guanine $+\left[{ }^{3} \mathrm{H}\right]$ methyl guanines d.p.m. The remaining $9.1 \%$ was partitioned among the four $\left[{ }^{3} \mathrm{H}\right]$ methyl guanines, as indicated.

TABLE 2. Incorporation of $\left.l^{3} \mathrm{H}\right]$ guanosine into astroglial tRNA

\begin{tabular}{|c|c|c|c|c|c|c|}
\hline $\begin{array}{c}{\left[{ }^{3} \mathrm{H}\right] \text { Guanosine }} \\
\text { incorporation } \\
\text { (h) }\end{array}$ & $\underset{(\%)}{\left[{ }^{3} \mathrm{H}\right] \text { Guanine }}$ & $\begin{array}{c}{\left[{ }^{3} \mathbf{H}\right] \text { methyl }} \\
\text { guanines } \\
(\%)\end{array}$ & $\begin{array}{c}{\left[{ }^{3} \mathrm{H}\right] 7-\mathrm{mG}} \\
(\%)\end{array}$ & $\begin{array}{c}{\left[{ }^{3} \mathrm{H}\right] \mathrm{N}^{2}-\mathrm{mG}} \\
(\%)\end{array}$ & $\begin{array}{c}{\left[{ }^{3} \mathrm{H}\right] 1-\mathrm{mG}} \\
(\%)\end{array}$ & $\begin{array}{c}{\left[{ }^{3} \mathrm{H}\right] \mathrm{N}_{2}^{2}-\mathrm{mG}} \\
(\%)\end{array}$ \\
\hline $1-3^{a}$ & 92.2 & 7.8 & $\begin{array}{r}3.32 \\
(42.7)\end{array}$ & $\begin{array}{r}1.32 \\
(17.0)\end{array}$ & $\begin{array}{r}2.90 \\
(37.3)\end{array}$ & $\begin{array}{c}0.22 \\
(3.0)\end{array}$ \\
\hline 4 & 87.4 & 12.6 & $\begin{array}{r}8.12 \\
(54.4)\end{array}$ & $\begin{array}{r}1.23 \\
(9.7)\end{array}$ & $\begin{array}{r}2.59 \\
(31.8)\end{array}$ & $\begin{array}{r}0.63 \\
(4.1)\end{array}$ \\
\hline 7.5 & 90.8 & 9.2 & $\begin{array}{r}3.60 \\
(39.1)\end{array}$ & $\begin{array}{r}2.81 \\
(30.5)\end{array}$ & $\begin{array}{l}1.52 \\
(16.6)\end{array}$ & $\begin{array}{r}1.24 \\
(13.8)\end{array}$ \\
\hline
\end{tabular}

The radioactivity in $\left[{ }^{3} \mathrm{H}\right]$ guanine $+\left[{ }^{3} \mathrm{H}\right]$ methyl guanines was: $10,578,82,424$ and 64,553 d.p.m. at $1-3,4$, and 7.5 h. A DEAE-cellulose purified preparation (see Methods) of $\left[{ }^{3} \mathrm{H}\right] \mathrm{tRNA}$ was used for total acid hydrolysis.

The numbers in parentheses refer to the percentage of the d.p.m. in the methyl guanine relative to $100 \%$ in their sum.

${ }^{a}$ Dishes exposed to $\left[{ }^{3} \mathrm{H}\right]$ guanosine for 1 and $3 \mathrm{~h}$ were pooled before extraction.

experimental period studied. Peak labeling of the methylguanines occurred at $4 \mathrm{~h}$, at which time $\left[{ }^{3} \mathrm{H}\right] 7$-methylguanine accounted for $8.12 \%$ of the total and $54.4 \%$ of the $\left[{ }^{3} \mathrm{H}\right]$ methyl guanine radioactivity. $\left[{ }^{3} \mathrm{H}\right] 1$-Methylguanine was maximally labeled within the first $3 \mathrm{~h}$, but by $7.5 \mathrm{~h}$ its radioactivity had decayed to half of its early value. The incorporation of $\left[{ }^{3} \mathrm{H}\right]$ guanosine into $\left[{ }^{3} \mathrm{H}\right] \mathrm{N}^{2}$-methylguanine more than doubled between $1-3$ and $7.5 \mathrm{~h}$, whereas that entering $\left[{ }^{3} \mathrm{H}\right] \mathrm{N}_{2}^{2}$-dimethylguanine increased about six- and fourfold relative to the overall and the methyl guanine radioactivities, respectively. These results indicate a rather independent temporal pattern of labeling of each methylguanine.

\section{Incorporation of $\left[{ }^{3} \mathbf{H}\right]$ Guanosine into Brain tRNA In Vivo}

Three-day-old rats were injected intracranially with $\left[{ }^{3} \mathrm{H}\right]$ guanosine (see Methods); groups of 10 animals were killed $5,10,20$, and 45 min later. The brain TRNA was extracted and purified by DEAEcellulose chromatography, and its radioactivity and $\mathbf{A}_{260} / \mathbf{A}_{280}$ absorbance ratio were determined. The average yield of tRNA in the $0.7 \mathrm{M}-\mathrm{NaCl}$ DEAEcellulose effluent was $5 A_{260}$ units/g of brain or about $2.2 A_{260}$ units per brain. The $\left[{ }^{3} \mathrm{H}\right] \mathrm{t}$ RNA was further purified by BDC chromatography, resulting in two separate fractions, a "salt" fraction (eluted 
TABLE 3. Effect of labeling time on the specific radioactivity ${ }^{a}$ of brain $\left.{ }^{3} \mathrm{H}\right] \mathrm{tRNA}$

\begin{tabular}{lccccc}
\hline & & \multicolumn{5}{c}{ Labeling time, min } \\
\cline { 3 - 6 } $\begin{array}{c}\text { Chromatographic } \\
\text { fraction }\end{array}$ & $\left(\mathrm{A}_{260}\right)$ & 5 & 10 & 20 & 45 \\
\hline DEAE-cellulose & 16.8 & 430 & 930 & 1300 & 2480 \\
BDC "salt" & 10.0 & 1719 & 2718 & 4440 & 5030 \\
"ethanol salt", & 1.5 & 6450 & 8920 & 27,100 & 26,100 \\
"ethanol salt" "'salt" & & 3.7 & 3.3 & 6.1 & 5.2 \\
\hline
\end{tabular}

${ }^{a}$ Values in d.p.m./ $\mathbf{A}_{260}$.

with a gradient of $0.5-1.0 \mathrm{M}-\mathrm{NaCl}, \mathrm{pH} 5.0$ ) and an "ethanol-salt" fraction (eluted with a gradient of $0-30 \% \mathrm{v} / \mathrm{v}$ EtOH in $1 \mathrm{M}-\mathrm{NaCl}, \mathrm{pH} 5.0$ ). About $85 \%$ of the recovered $\mathrm{A}_{260}$ units was found in the "salt" and the remaining $15 \%$ in the "ethanol-salt" fraction. Table 3 shows the specific radioactivity (s.r.a.) of the $\left[{ }^{3} \mathrm{H}\right]$ tRNA and Fig. 3 the location within the BDC effluent of the tRNA ${ }^{\text {lys }}$ and tRNA ${ }^{\text {phe }}$ isoacceptors determined in experiments in which DEAE-cellulose-purified tRNA was separately charged with $\left[{ }^{14} \mathrm{C}\right]$ lysine or $\left[{ }^{14} \mathrm{C}\right]$ phenylalanine. the aminoacyl $\left[{ }^{14} \mathrm{C}\right]$ tRNA then being chromatographed on BDC. As illustrated in Fig. 3, 3-day-old rat brain has three tRNA ${ }^{\text {lys }}$ isoacceptors, the most abundant one of which was eluted in the "salt" fraction, while the two minor isoacceptor species were eluted in the "ethanol-salt" fraction, which also contained all of the tRNA ${ }^{\text {phe }}$ isoacceptors.

Total tRNA labeling (d.p.m./ $\mathbf{A}_{\mathbf{2 6 0}}$ ) appeared to increase about sixfold between 5 and 45 min (Table 3, row 1). Labeling of the tRNA species resolved by BDC chromatography (rows 2 and 3, Table 3), appeared to proceed more slowly and at different rates in the "salt" versus the "ethanol-salt" fraction. Moreover, the "ethanol-salt" fraction contained
tRNAs of much higher relative purity than the "salt" fraction, as indicated by the "ethanolsalt"/"salt" ratios.

As above with the $\left[{ }^{3} \mathrm{H}\right]$ tRNA from astrocytes (Table 2), brain $\left[{ }^{3} \mathrm{H}\right]$ tRNA was hydrolyzed, its $\left[{ }^{3} \mathrm{H}\right]-$ guanine and $\left[{ }^{3} \mathrm{H}\right]$ methyl guanines separated by HPLC and their radioactivities determined. The distribution of the radioactivity (Table 4) favored overwhelmingly the unmodified guanine residues, although 7-and $\mathrm{N}^{2}$-methylguanine were also labeled from the start, their labeling remaining sustained for $45 \mathrm{~min}$. $\mathrm{N}_{2}^{2}$-Dimethylguanine first became labeled at $20 \mathrm{~min}$, while $\left[{ }^{3} \mathrm{H}\right.$ ] 1-methylguanine was not detected at any time.

\section{Attempts to Isolate tRNA ${ }^{\text {phe }}$ from Rat Brain}

In order to obtain more reliable information about the pattern of labeling of tRNA guanine and methyl guanine residues, and also to assess the feasibility of isolating a single labeled tRNA species, a largescale experiment was carried out in which 53 3day-old rats were injected with $\left[{ }^{3} \mathrm{H}\right]$ guanosine, their brains being processed for $\left[{ }^{3} \mathrm{H}\right] \mathrm{tRNA}{ }^{\text {phe }}$ purification

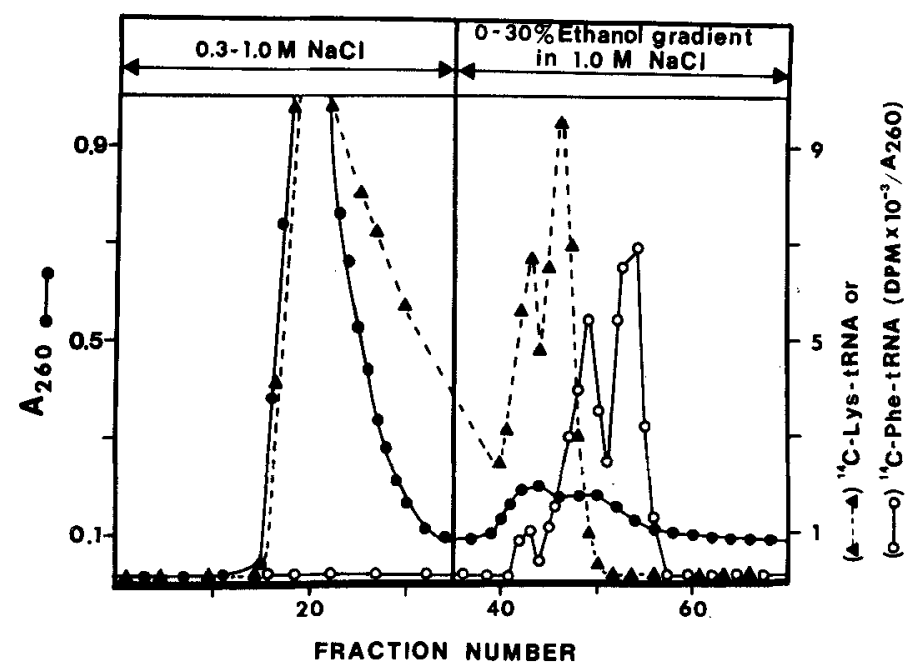

FIG. 3. Separation of tRNA and tRNA isoacceptors from 3-day-old rat brain by BDC chromatography. The [ $\left.{ }^{3} \mathrm{H}\right]$ tRNA was extracted from 3-day-old rat brain and was purified by passage through DEAE-cellulose (see Methods). Approximately $90 \mathrm{~A}_{260}$ absorbance units were loaded on the BDC column. For details, see Methods. Aliquots $(0.5 \mathrm{ml})$ of the effluent were tested for $\left[{ }^{14} \mathrm{C}\right] \mathrm{lysine}$ and $\left[{ }^{14} \mathrm{C}\right]$ phenylalanine acceptance, also as described in Methods. 
TABLE 4. Incorporation of $\left[{ }^{3} \mathrm{H}\right]$ guanosine into rat brain $t R N A$

\begin{tabular}{|c|c|c|c|c|c|c|}
\hline $\begin{array}{l}\text { Age } \\
\text { (days) }\end{array}$ & $\begin{array}{c}{\left[{ }^{3} \mathrm{H}\right] \text { Guanosine }} \\
\text { pulse } \\
\text { (min) }\end{array}$ & $\begin{array}{c}{\left[{ }^{3} \mathrm{H}\right] \text { Guanine }} \\
(\%)\end{array}$ & $\begin{array}{c}{\left[{ }^{3} \mathrm{H}\right] \text { Methyl }} \\
\text { guanines } \\
(\%)\end{array}$ & 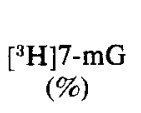 & $\begin{array}{c}{\left[{ }^{3} \mathbf{H}\right] \mathrm{N}^{2}-\mathrm{mG}} \\
(\%)\end{array}$ & $\begin{array}{c}{\left[{ }^{3} \mathrm{H}\right] \mathrm{N}_{2}^{2}-\mathrm{mG}} \\
(\%)\end{array}$ \\
\hline 3 & 5 & 96.3 & 3.7 & $\begin{array}{c}2.1 \\
(57.5)\end{array}$ & $\begin{array}{c}1.6 \\
(42.5)\end{array}$ & n.d. \\
\hline 3 & 10 & 97.5 & 2.5 & $\begin{array}{c}1.2 \\
(47.3)\end{array}$ & $\begin{array}{c}1.2 \\
(52.7)\end{array}$ & n.d. \\
\hline 18 & 10 & 92.5 & 7.5 & $\begin{array}{c}5.0 \\
(67.3)\end{array}$ & $\begin{array}{c}2.5 \\
(32.7)\end{array}$ & n,d. \\
\hline 3 & 20 & 94.7 & 5.3 & $\begin{array}{c}2.1 \\
(40.4)\end{array}$ & $\begin{array}{c}2.2 \\
(42.2)\end{array}$ & $\begin{array}{c}1.0 \\
(17.4)\end{array}$ \\
\hline 18 & 20 & 94.7 & 5.3 & $\begin{array}{c}3.5 \\
(68.5)\end{array}$ & $\begin{array}{c}1.8 \\
(31.5)\end{array}$ & n.d. \\
\hline 3 & 45 & 94.5 & 5.5 & $\begin{array}{c}2.3 \\
(43.0)\end{array}$ & $\begin{array}{c}2.2 \\
(38.9)\end{array}$ & $\begin{array}{c}1.0 \\
(18.1)\end{array}$ \\
\hline 18 & 45 & 95.3 & 4.7 & $\begin{array}{c}2.4 \\
(46.0)\end{array}$ & $\begin{array}{c}1.3 \\
(30.5)\end{array}$ & $\begin{array}{c}1.0 \\
(23.5)\end{array}$ \\
\hline
\end{tabular}

n.d.: not detected. The radioactivity in $\left[{ }^{3} \mathrm{H}\right]$ guanine $+\left[{ }^{3} \mathrm{H}\right]$ methyl guanines of the 3-day-old tRNA was: 7208 , $15,668,20,695$, and 41,780 d.p.m. at 5, 10, 20, and $45 \mathrm{~min}$. For the 18-day-old tRNA, the values were: 16,302, 28,838, and 29,052 d.p.m. at 10,20 , and 45 min.

The numbers in parentheses refer to the percentage of the d.p.m. in the methyl guanine relative to $100 \%$ in the sum of all methyl guanines.

45 min later. Portions of the DEAE-cellulose and of the "salt" and "ethanol-salt" BDC effluent fractions, as well as three pools of the RPC-5 effluent, were subjected to total hydrolysis and subsequent HPLC. In this fashion, it became possible to follow the $\left[{ }^{3} \mathrm{H}\right]$ guanine $+\left[{ }^{3} \mathrm{H}\right]$ methyl guanine composition of $\left[{ }^{3} \mathrm{H}\right]$ tRNA at different stages of the tRNA ${ }^{\text {phe }}$ purification procedure. The results (Table 5) reveal significant differences in composition between the three RPC-5 subfractions and they also disclose an apparent similarity between the BDC "salt" and "ethanol-salt" fractions. The RPC-5 fraction containing the tRNA with peak acceptance for phenylalanine (fraction I) appeared to contain a higher proportion of labeled 7- and $\mathrm{N}_{2}^{2}-$ dimethylguanine than its neighbor and no detectable labeled 1- and $\mathrm{N}^{2}$-methylguanine. Fraction II con- tained all but $\left[{ }^{3} \mathrm{H}\right] 7$-methylguanine, while fraction III resembled the $\left[{ }^{3} \mathrm{H}\right]$ tRNA ${ }^{\text {phe }}$-containing fraction I, yet had a much lower $\left[{ }^{3} \mathrm{H}\right] \mathrm{N}_{2}^{2}$-dimethylguanine content.

\section{Methyl Guanine Labeling Patterns in Astrocyte and Brain tRNA}

Although in this study we monitored the biosynthesis of tRNA both in the 3-day-old rat brain and in fully differentiated astrocytes derived from the 3day-old rat brain, a direct comparison of the labeling patterns of the methylated guanines in the two neural systems is not possible, principally because of the different temporal parameters governing their formation, hours in astrocytes and minutes in the live animal. Yet, while the labeling of 1-methyl-

TABLE 5. Incorporation of $\left[{ }^{3} H\right]$ guanosine into brain $t R N A^{\text {phr }}, t R N A^{\text {lys }}$, and other $t R N A s$

\begin{tabular}{|c|c|c|c|c|c|c|}
\hline $\begin{array}{l}\text { Purification } \\
\text { step }\end{array}$ & $\underset{(\%)}{\left[{ }^{3} \mathrm{H}\right] \text { Guanine }}$ & $\begin{array}{c}{\left[{ }^{3} \mathbf{H}\right] \text { Methyl }} \\
\text { guanines } \\
(\%)\end{array}$ & $\begin{array}{c}{\left[{ }^{3} \mathrm{H}\right] 7-\mathrm{mG}} \\
(\%)\end{array}$ & $\begin{array}{c}{\left[{ }^{3} \mathrm{H}\right] \mathrm{N}^{2}-\mathrm{mG}} \\
(\%)\end{array}$ & $\begin{array}{c}{\left[{ }^{3} \mathrm{H}\right] 1-\mathrm{mG}} \\
(\%)\end{array}$ & $\begin{array}{c}{\left[{ }^{3} \mathrm{H}\right] \mathrm{N}_{2}^{2}-\mathrm{mG}} \\
(\%)\end{array}$ \\
\hline DEAE-cellulose & 89.5 & 10.5 & 4.5 & 2.4 & 1.3 & 2.3 \\
\hline BDC "salt" & 91.5 & 8.5 & 3.5 & 2.3 & 1.1 & 1.6 \\
\hline "Ethanol salt" & 90.6 & 9.4 & 3.5 & 2.9 & 1.7 & 1.3 \\
\hline \multicolumn{7}{|l|}{$\begin{array}{l}\text { RPC-5 of BDC- } \\
\text { "ethanol salt" } \\
\text { fraction }\end{array}$} \\
\hline Tubes $1-47$ (I) & 88.3 & 11.7 & 5.8 & n.d. & n.d. & 5.9 \\
\hline Tubes $48-53$ (II) & 93.4 & 6.6 & n.d. & 1.4 & 2.6 & 2.6 \\
\hline Tubes $54-80$ (III) & 93.8 & 6.2 & 4.3 & n.d. & n.d. & 1.9 \\
\hline
\end{tabular}

n.d.: not detected.

The 3-day-old animals were killed $45 \mathrm{~min}$ after the administration of $\left[{ }^{3} \mathrm{H}\right]$ guanosine (see Methods).

${ }^{a}$ Phenylalanine acceptance was highest $\left(707 \mathrm{pmol} / \mathrm{A}_{260}\right)$ in tube 47 , in which lysine acceptance was nil. Lysine acceptance was highest $\left(1930 \mathrm{pmol} / \mathrm{A}_{260}\right)$ in tube 11 , in which phenylalanine acceptance was nil. Phenylalanine acceptance was $17.5 \mathrm{pmol} / \mathrm{A}_{260}$ in tube 50 , in which lysine acceptance was nil. No phenylalanine or lysine acceptance was detected in tubes $54-80$. 
guanine was very rapid and intense in astrocyte tRNA, and virtually nonexistent in brain tRNA, that of $\mathrm{N}^{2}$-methylguanine appeared to be characteristic for each of the two systems under study (Fig. 4).

\section{DISCUSSION}

The exposure of the astrocytes to $\left[{ }^{3} \mathrm{H}\right]$ guanosine resulted in a very low degree of incorporation of ${ }^{3} \mathrm{H}$ into cellular RNA during the initial $3 \mathrm{~h}$. The rate of labeling increased, however, between the 3rd and 4th $h$, abating considerably thereafter. Figure 1, parts $B$ and $C$, indicates that the labeling and the specific radioactivity of tRNA increased gradually from the very start and did so, apparently, in the face of a progressive decrease, past hour 3 , in the proportion of the radioactivity incorporating into tRNA, as opposed to total RNA. At present we have no explanation for the sharp decrease in the ratio of labeled tRNA to total RNA shown by Fig. $1, \mathrm{C}$. Since we made no effort to characterize the modalities of $\left[{ }^{3} \mathrm{H}\right]$ guanosine transport, countertransport, and metabolism, as recently done by

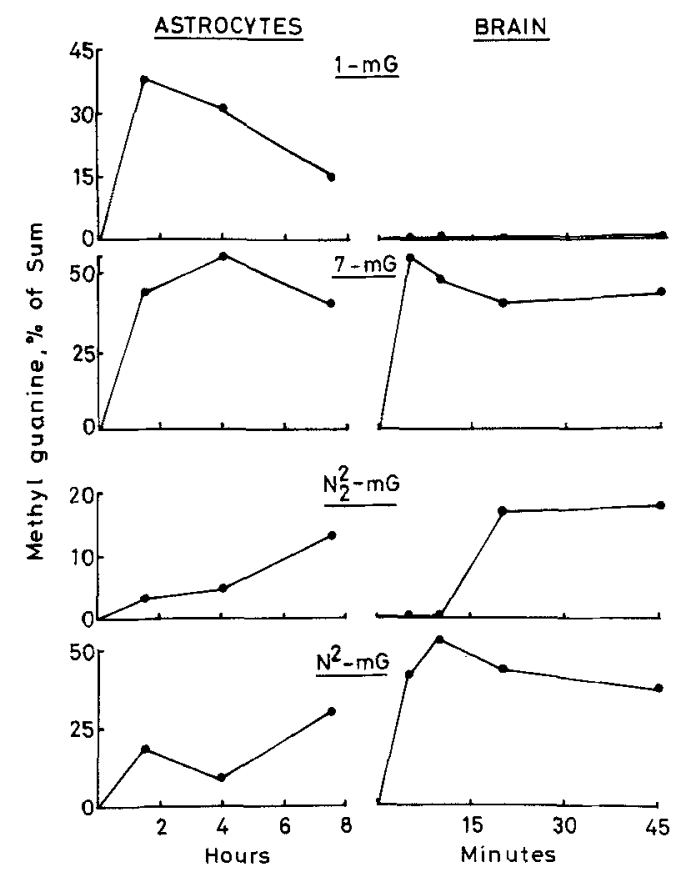

FIG. 4. Time course of labeling of the individual $\left[{ }^{3} \mathrm{H}\right]$ methyl guanines. The $\left[{ }^{3} \mathrm{H}\right]$ guanosine-labeled (hours for astrocytes, minutes for brain) tRNA was isolated from astrocytes and 3-day-old rat brain at the times indicated and was purified by passage through DEAE-cellulose (see Methods). Hydrolysis in trifluoroacetic acid and HPLC separation of the $\left[{ }^{3} \mathrm{H}\right]$ bases was as described in Methods. The radioactivity recovered in the sum of the $\left[{ }^{3} \mathrm{H}\right]$ methyl guanines was set at $100 \%$ and the percentage distribution of the d.p.m. among $\left[{ }^{3} \mathrm{H}\right] 1$-methyl, 7-methyl, $\mathrm{N}_{2}^{2}$, and $\mathrm{N}^{2}$-methylguanine is plotted.
Snyder et al. (1978) and May and Hoffee (1978) with neuroblastoma and Novikoff hepatoma cells, it is not known whether the normal astrocytes used in this study possess specialized high-affinity mechanisms for the uptake of guanosine, as they do for adenosine (Hertz, 1978). It is of interest, however, that Yanagihara (1979) found the uptake of $1 \mu \mathrm{M}$ guanosine into bulk-isolated rabbit cortex glial cells to be 6.5-fold more effective than it is into "intact" neuronal perikarya.

The partially purified astrocyte and brain tRNAs were aminoacylated under assay conditions optimized with brain tRNA for lysine and phenylalanine acceptance with regard to $\left[\mathrm{Mg}^{\mathbf{2}}\right],\left[\mathrm{K}^{+}\right]$, and [ATP] (Johnson and Chou, 1973). Table 1 indicates significantly lower acceptance values for lysine and phenylalanine with astrocyte than with brain tRNA, irrespective of the source of the aminoacyl-tRNA synthetase. Yet, lysine and phenylalanine acceptance was higher in the presence of the hepatic enzyme, with either kind of tRNA, in confirmation of results of others (Barra et al., 1972; Johnson and Chou, 1973; Harris and Maas, 1974). Moreover, a homologous lysine acceptance of $22.4 \mathrm{pmol} / \mathrm{A}_{\mathbf{2 6 0}} / \mathrm{mg}$ protein by 3 -day-old rat brain tRNA (Table 1) agrees well with the calculated value of $20 \mathrm{pmol} / \mathrm{A}_{260} / \mathrm{mg}$ protein reported by Barra et al. (1972), for 4-day-old rat brain tRNA. Phenylalanine acceptance values [1.78 (Table 1) and $7.5 \mathrm{pmol} / \mathrm{A}_{260} / \mathrm{mg}$ protein (Barra et al., 1972)] agreed less well. No adequate explanation for the low acceptance values of astrocyte tRNA is available at this time; however, the assays were not individually optimized owing to its relatively low availability and the fact that the tRNA preparations were not deacylated before use. Since the acceptance values were derived from tRNAs of cells grown in culture for 19 days, they ought to be compared to older than 3-day-old rat brain tRNA acceptance values and these, as shown by Barra et al. (1972), do decrease appreciably between 4 and 55 days of postnatal life.

The results of the experiments on the incorporation of $\left[{ }^{3} \mathrm{H}\right]$ guanosine into neural tRNAs (Tables $2-5$ ) reveal that cultured astrocytes and immature brain are well suited for investigations of the cellspecific nature of tRNA biosynthesis and modification. Since, relative to the tRNA of 3-day-old brain (Table 4), which reflects a largely neuronal cellular template, astrocyte tRNA (Table 2) showed a significantly higher ratio of methylated to unmodified guanine(s), it is possible to suggest that the incorporation results mirror real, albeit subtle, differences in methyl guanine content between some, if not all, glial and neuronal tRNAs. Supportive evidence for this notion may be seen in the distribution of the individual $\left[{ }^{3} \mathrm{H}\right]$ methyl guanines within astrocyte and brain tRNA at the end of their respective labeling periods $\left(45 \mathrm{~min}\right.$ versus $7.5 \mathrm{~h}$ ). Although $\left[{ }^{3} \mathrm{H}\right] 7$ - and $\mathrm{N}^{2}$-methylguanine appeared to predominate in both 
tRNAs and accounted for up to $80 \%$ of the total $\left[{ }^{3} \mathrm{H}\right]$ methyl guanines, the remaining $20-25 \%$ was shared by $\left[{ }^{3} \mathrm{H}\right] \mathrm{N}_{2}^{2}$-dimethyl- and $\left[{ }^{3} \mathrm{H}\right] 1$-methylguanine in astrocyte tRNA; but significantly the latter species was never detected in: (a) bulk brain tRNA (Table 4); (b) RPC-5 fraction I (Table 5), containing tRNAs with the highest phenylalanine and lysine acceptance capacities and (c) RPC-5 fraction III, which contained no tRNA $A^{\text {phe }}$ or tRNA ${ }^{\text {lys }}$. Interestingly, however, $\left[{ }^{3} \mathrm{H}\right] 1$-methylguanine was present in RPC-5 fraction II, which contained some tRNA $^{\text {phe }}$, no tRNA ${ }^{l y s}$, and, unlike fractions I and III, no $\left[{ }^{3} \mathrm{H}\right] 7$-methylguanine. RPC-5-chromatography of the BDC "ethanol-salt" fraction of 3-dayold rat brain tRNA thus proved effective in separating tRNAs containing $\left[{ }^{3} \mathrm{H}\right] 1$-methylguanine from those containing $\left[{ }^{3} \mathrm{H}\right] 7$-methylguanine.

As a result of our continued interest in neural tRNA during development, it is now clear that tRNA biosynthesis and tRNA methylation are cellspecific. Each process can be studied in vivo (this paper), in whole brain minces (Elahi and Sellinger, 1979), in brain regions (Sellinger et al., 1979; Dainat and Sellinger, 1980), and in specific cell types, bulk-isolated (Salas and Sellinger, 1978) or grown in culture (this paper). A sustained and correct structural adjustment of neural tRNAs thus appears as a prerequisite for the successful synthesis of those neural proteins which are essential for the acquisition of a particular neural function at a precise and nonrecurrent time during brain development.

\section{ACKNOWLEDGMENT}

This work was supported in part by the United States Public Health Service, NINCDS, 06294. The excellent technical assistance of Mrs. Denise Bond and $\mathrm{Mr}$. Wayne G. Ohlsson is gratefully acknowledged.

\section{REFERENCES}

Azcurra J. M., Sellinger O. Z., and Carrasco A. E. (1975) In vivo labelling of cytoplasmic RNA in neurons of the immature brain cortex. Brain Res. 86, 144-149.

Barra H. S., Unates L. E., Sayavedra M. S., and Caputto R. (1972) Capacities for binding amino acids by tRNAs from rat brain and their changes during development. J. Neurochem. $19,2289-2297$.

Cummins C. J. and Glover R. A. (1978) Propagation and histological characterization of a homotypic population of astrocytes derived from neonatal rat brain. J. Anat. 125, $117-125$.

Cummins C. J., Salas C. E., and Sellinger O. Z. (1975) The homologous methylation of tRNA in rat brain. Brain Res. 96 407-412.

Cummins C. J., Glover R. A., and Sellinger O. Z. (1979) Astroglial uptake is modulated by extracellular $\mathrm{K}^{+} . J$. Neurochem. 33, 779-785.

Dainat J. and Sellinger O. Z. (1980) Cerebellar tRNA methyltransferases: A developmental study. Brain Res. 183, $133-141$.
Dainat J., Salas C. E., and Sellinger O. Z. (1978) Alteration of the specificity of brain tRNA methyltransferases and of the pattern of brain tRNA methylation in vivo by methionine sulfoximine. Biochem. Pharmacol. 27, 2655-2658.

Elahi E. and Sellinger O. Z. (1979) The postnatal methylation of transfer ribonucleic acid in brain: Evidence for the methylation of precursor transfer ribonucleic acid. Biochem. J. 177, $381-384$.

Flangas A. and Bowman R. E. (1970) Differential metabolism of RNA in neuronal-enriched and glial-enriched fractions of rat cerebrum. J. Neurochem. 17, 1237-1245.

Harris C. L. and Maas J. W. (1974) Transfer RNA and the regulation of protein synthesis in rat cerebral cortex during neural development. $J$. Neurochem. 22, 741-749.

Hertz L. (1978) Kinetics of adenosine uptake into astrocytes. $J$. Neurochem. 31, 55-62.

Jarlstedt J. and Hamberger A. (1971) Patterns and labelling characteristics in neuronal and glial RNA. J. Neurochem. 18, 921-930.

Johnson T. C. and Chou L. (1973) Level and amino acid acceptor activity of mouse brain tRNA during neural development. $J$. Neurochem. 20, 405-414.

Judes C. and Jacob M. (1973) Differentiation of chick embryo cerebral hemispheres. II. Incorporation of $\left[{ }^{3} \mathrm{H}\right]$-uridine into 29 S, 18 S, 5 S and 4 S RNA. Brain Res. 51, 253-267.

Kelmers A. D. and Heatherly D. E. (1971) Columns for rapid chromatographic separation of small amounts of tracerlabelled transfer ribonucleic acids. Anal. Biochem. 44, 486-495.

Klagsbrun M. (1972) The contrast between the methylation of transfer ribonucleic acid in vivo and in vitro by normal and SV40 transformed 3T3 cells. J. Biol. Chem. 247, 7443-7451.

Kubat B., Moren G. M., and von der Decken A. (1978) DNAdependent RNA polymerase from rat brain, and RNA synthesis in glial and neuronal cell-enriched fractions after protein restriction. $J$. Neurochem. 31, 1143-1148.

Lowry O. H., Rosebrough N. J., Farr A. L., and Randall R. J. (1951) Protein measurement with the Folin phenol reagent. J. Biol. Chem. 193, 265-275.

May R. A. and Hoffee P. (1978) Guanosine metabolism in Novikoff hepatoma cells: Isolation and characterization of guanosine resistant variants. Arch. Biochem. Biophys. 190, $712-718$.

Ortwerth B. J. and Chu-Der O. M. Y. (1974) Studies on the specialized transfer RNA population of the lens. Exp. Eye Res. $19,521-532$.

Roy K. L., Bloom A., and Soll D. (1971) tRNA separations using benzoylated DEAE-cellulose, in Procedures in Nucleic Acids Research, Vol. 2 (Cantoni G. L. and Davis D. R., eds), pp. 524-541. Harper and Row, New York.

Saborio J. L. and Aleman V. (1970) Study of RNA in subcellular fractions from rat brain: Simultaneous incorporation of $\left[{ }^{14} \mathrm{C}\right]$-uridine and $\left[{ }^{3} \mathrm{H}\right]$-methyl-L-methionine. J. Neurochem. 17, 91-101.

Salas C. E. and Sellinger O. Z. (1977) Rapid, quantitative separation by high-performance liquid chromatography of methylated bases in transfer RNA. J. Chromatogr. 133, 231-236.

Salas C. E. and Sellinger O. Z. (1978) Methylation of E. coli transfer ribonucleic acids by a tRNA adenine-1methyltransferase from rat brain cortex and bulk-isolated neurons. J. Neurochem. 31, 85-91.

Salas C. E., Cummins C. J., and Sellinger O. Z. (1976) The developmental pattern of homologous and heterologous tRNA methylation in rat brain: Differential effect of spermidine. Neurochem. Res. 1, 369-384.

Sellinger O. Z. and Salas C. E. (1980) Transfer RNA's in brain, in Biochemistry of Brain (Kumar S., ed), pp. 283-301. Pergamon Press, Oxford.

Sellinger O. Z., Dainat J., and Salas C. E. (1977) The relationship of tRNA methylation to brain protein synthesis during cortical and cerebellar development, in Mechanisms, Reg- 
ulation and Special Functions of Protein Synthesis in the Brain (Roberts S., Lajtha A., and Gispen W. H. eds), pp. 55-70. Elsevier/North Holland Biomedical Press Amsterdam-New York.

Snyder F. F., Cruikshank M. K., and Seegmiller E. (1978) A comparison of purine metabolism and nucleotide pools in normal and hypoxanthine-guanine phosphoribosyltransferase-deficient neuroblastoma cells. Biochim. Biophys. Acta 543, 556-569.

Tewari S., Fleming E. W., and Noble E. P. (1975) Alterations in brain RNA metabolism following chronic ethanol ingestion. J. Neurochem. 24, 561-569.
Volpe P. and Giuditta A. (1967) Kinetics of RNA labelling in fractions enriched with neuroglia and neurones. Nature 216, 154.

Yanagihara T. (1979) Protein and RNA syntheses and precursor uptake with isolated nerve and glial cells. J. Neurochem. 32, $169-177$.

Yang W. K. and Novelli G. D. (1971) Analysis of isoaccepting tRNAs in mammalian tissues and cells, in Methods in Enzymology, Vol. XX, Part C (Moldave K. and Grossman L., eds), pp. 44-55. Academic Press, New York. 